\title{
Penerapan Media Sosial bagi Peningkatan Kinerja UMKM di Kota Jambi
}

\author{
Firdaus, Fahrizal \\ Program Studi Ilmu Pemerintahan, STISIP Nurdin Hamzah Jambi, Indonesia \\ Correspondence email: firdaussudirmanz@gmail.com
}

\begin{abstract}
Abstrak. Tujuan penelitian ini adalah untuk mendeskripsikan peran media sosial dan kinerja UMKM di Kota Jambi, serta pengaruh peran media sosial terhadap kinerja bisnis. Data penelitian diperoleh melalui metode survey dengan menggunakan kuesioner yang diberikan kepada 60 responden. Data tersebut dianalisis dengan menggunakan teknik analisis regresi linear sederhana. Hasil analisis menunjukkan bahwa peran media sosial, yang direfleksikan oleh dimensi curation, consumption, creation, dan collaboration secara keseluruhan mendapatkan rata-rata perolehan skor pada rentang 3,41-4,20 dengan kriteria "baik". Kinerja UMKM yang direfleksikan oleh pertumbuhan jumlah penjualan, pertumbuhan pangsa pasar, dan pertumbuhan keuntungan mendapatkan rata-rata perolehan skor pada rentang 3,41-4,20 dengan kriteria "tinggi". Berdasarkan hasil pengujian hipotesis juga telah membuktikan bahwa peran media sosial berpengaruh positif dan signifikan terhadap kinerja UMKM di Kota Jambi.
\end{abstract}

Kata kunci: Kinerja; Media Sosial; UMKM

Abstract. The purpose of this study is to describe the role of social media and small and medium micro enterprises performance in Jambi City, as well as the influence of the role of social media on business performance. The research data were obtained through a survey method using a questionnaire given to 60 respondents. The data is analyzed using simple linear regression analysis techniques. The analysis shows that the role of social media, which is reflected by the dimensions of curation, consumption, creation, and collaboration as a whole get an average score acquisition in the range of 3.41-4.20 with "good" criteria. The performance of small and medium micro enterprises which is reflected by the growth in the number of sales, growth in market share, and profit growth get an average score in the range of 3.41-4.20 with "high" criteria. Based on the results of hypothesis testing has also proven that the role of social media has a positive and significant effect on the performance of small and medium micro enterprises in Jambi City.

\section{Keyword: Performance; Social Media; UMKM}

\section{PENDAHULUAN}

Dunia digital diprediksi akan menjadi poin krusial bagi seluruh aktivitas manusia, termasuk aktivitas bisnis. Menurut we are social, ada kenaikan pengguna internet di Indonesia selama setahun, mulai Januari 2015 sampai Januari 2016, sekitar 15 persen. Survei yang dilakukan we are social tersebut, menggambarkan bahwa pengguna internet mengalami peningkatan. Sebagian besar dari masyarakat Indonesia mulai menyadari akan keberadaan internet, bahkan saat ini internet bukan hanya sekedar media untuk mencari informasi, komunikasi dan hiburan saja melainkan sebagai sarana untuk bisnis online (bisnis melalui media internet). Pesatnya perkembangan teknologi, dunia digital dan internet tentu juga berimbas pada dunia pemasaran. Tren pemasaran di dunia beralih dari yang semula konvensional (offline) menjadi digital (online). Globalisasi pasar telah mempengaruhi perilaku perdagangan yang selalu berusaha untuk memenuhi kebutuhan konsumen. Globalisasi pasar menuntut Usaha Mikro Kecil Menengah (UMKM) untuk dapat mengikuti perkembangan pasar agar dapat bertahan dan meningkatkan penjualan pada bisnisnya.

UMKM mempunyai peranan yang penting dalam pertumbuhan ekonomi dan industri suatu negara (Husband and Purnendu, 1999; Mahemba, 2003; Tambunan, 2005). Usaha kecil penting untuk dikaji karena mempunyai peranan yang krusial dalam pertumbuhan ekonomi pada skala nasional dan regional. Hampir $90 \%$ dari total usaha yang ada di dunia merupakan kontribusi dari UMKM (Lin, 1998). Disamping itu, UMKM mempunyai kontribusi terhadap penyerapan tenaga kerja (Tambunan, 2005). Studi empirik menunjukkan bahwa UMKM pada skala internasional merupakan sumber penciptaan lapangan pekerjaan (Olomi, 1999; Lin, 1998; Westhead and Cowling, 1995). Banyaknya UMKM ini tentu disebabkan karena produk-produk dari UMKM sangat diminati bahkan dibutuhkan oleh masyarakat. Namun demikian tidak semua produk-produk dari UMKM dikenal luas oleh masyarakat. Pemanfaatan pemasaran melalui media digital (digital marketing) masih belum maksimal jika dibandingkan dengan pertumbuhan jumlah pengguna internet yang drastis. Berdasarkan hasil riset McKinsey, baru sekitar 30\% usaha di Indonesia yang menggunakan instrumen digital dalam mengembangkan usahanya (Supriadi, http://www.marketing.co.id, 2016).

Sebagaimana daerah lainnya di Indonesia, UMKM Kota Jambi juga telah berkembang pesat dan menunjukkan peran pentingnya dalam perekonomian masyarakat di daerah ini. Di Provinsi Jambi, tercatat sebanyak 81.959 UMKM, 
dengan Kota Jambi sebagai kota dengan jumlah UMKM terbesar yaitu 13.723 usaha (Dinas Koperasi dan UMKM Provinsi Jambi, 2015.(Renstra Diskop UMKM Kota Jambi, 2016).

Tabel 1.

Data Jumlah UMKM di Kota Jambi Tahun 2018

\begin{tabular}{|c|c|c|c|c|c|c|c|}
\hline \multirow{2}{*}{ Kecamatan } & \multicolumn{6}{|c|}{ Bidang Usaha } & \multirow{2}{*}{ Total } \\
\hline & Kuliner & Fashion & Otomotif & Agro & TI & Lainnya & \\
\hline Telanaipura & 452 & 60 & 42 & 1 & 63 & 577 & 1.195 \\
\hline Jambi Selatan & 499 & 55 & 26 & 4 & 17 & 246 & 847 \\
\hline Jambi Timur & 575 & 38 & 1 & 57 & 19 & 733 & 1.423 \\
\hline Pasar & 406 & 108 & 15 & 4 & 9 & 387 & 929 \\
\hline Danau Teluk & 401 & 69 & 3 & 0 & 3 & 180 & 656 \\
\hline Pelayangan & 281 & 60 & 7 & 2 & 8 & 243 & 601 \\
\hline Kota Baru & 242 & 55 & 39 & 0 & 11 & 389 & 736 \\
\hline Jelutung & 111 & 40 & 8 & 0 & 3 & 391 & 553 \\
\hline Alam Barajo & 435 & 63 & 42 & 0 & 19 & 557 & 1.116 \\
\hline Danau Sipin & 742 & 106 & 30 & 0 & 35 & 679 & 1.592 \\
\hline Paal Merah & 490 & 87 & 52 & 5 & 22 & 459 & 1.115 \\
\hline Total & 4.634 & 741 & 265 & 73 & 209 & 4.841 & 10.763 \\
\hline
\end{tabular}

Sumber: Dinas Tenaga Kerja, Koperasi, dan UMKM Kota Jambi (2018)

Berdasarkan survey awal yang telah dilakukan diketahui bahwa terdapat 40 UMKM yang menggunakan media sosial secara aktif dalam kegiatan perdagangan mereka, dengan komposisi kelompok usaha yang terdiri dari usaha kecil sebesar 34 usaha (85\%) dan usaha menengah sebesar 6 usaha (15\%). Hal ini menerangkan bahwa masih rendahnya penggunaan media sosial dalam aktivitas perniagaan pada UMKM di Kota Jambi. Salah satu kendala yang dihadapi oleh UMKM tersebut adalah terbatasnya pasar untuk mengembangkan pemasaran produk karena ketidakmampuan para pelaku usaha untuk melakukan praktik pemasaran yang efektif dan berbiaya rendah. Padahal, saat ini terdapat cukup banyak aplikasi yang menawarkan fitur-fitur yang dapat digunakan secara gratis untuk mempromosikan maupun menawarkan produk-produk yang dimiliki, diantaranya facebook yang menyediakan fitur facebook pages dan Instagram yang menyediakan fitur Instagram for Business.

Merujuk pada uraian latar permasalahan tersebut, maka perlu dilakukan kajian empiris mengenai pemanfaatan media sosial serta perannya bagi peningkatan kinerja UMKM di Kota Jambi. Adapun tujuan dari penelitian ini adalah untuk mendapatkan gambaran mengenai bagaimana peran media sosial yang selama ini digunakan oleh UMKM di Kota Jambi, serta seberapa besar dampaknya bagi kinerja UMKM tersebut.

\section{METODE}

Penelitian ini menggunakan metode penelitian survey dan termasuk ke dalam penelitian asosiatif dengan pendekatan korelasional. Sugiyono (2006:11) menerangkan bahwa penelitian asosiatif merupakan penelitian yang bertujuan untuk mengetahui hubungan antara variabel peran sosial media dengan variabel kinerja UMKM. Populasi dalam penelitian ini adalah para pelaku UMKM yang berada pada suatu wilayah tertentu yaitu di Kota Jambi dan memenuhi syarat-syarat tertentu berkaitan dengan masalah penelitian yakni memanfaatkan media sosial sebagai sarana komunikasi pemasaran. Pengambilan sampel dalam penelitian ini menggunakan teknik Pursposive Sampling, dimana pertimbangan yang digunakan adalah UMKM yang telah memanfaatkan media sosial sebagai sarana komunikasi pemasaran minimal selama dua tahun. Berdasarkan data yang diperoleh, tercatat 60 UMKM di Kota Jambi yang menggunakan media sosial. Dengan demikian jumlah sampel UMKM yang digunakan dalam penelitian ini adalah 60 UMKM.

Jenis data yang diambil dalam penelitian ini adalah data kuantitatif dan data kualitatif. Untuk data kuantitatif meliputi pemanfaatan media sosial dan kinerja UMKM. Sementara data kualitatif berupa buku, jurnal, artikel, dan sumber-sumber lain yang berkaitan dan memperkuat dasar penelitian serta sumber-sumber tertulis yang mengacu pada teori-teori yang ada. Data yang telah diperoleh dianalisis secara deskriptif melalui metode analisis deskriptif kualitatif untuk mendeskripsikan pemanfaatan media sosial dan kinerja UMKM. Selanjutnya untuk mengetahui pengaruh peran media sosial terhadap kinerja UMKM digunakan metode analisis regresi linear sederhana. Metode ini digunakan untuk meramalkan perubahan nilai variabel kinerja $(\mathrm{Y})$ yang diakibatkan oleh perubahan nilai pada variabel peran media sosial (X). Di dalam analisis regresi linear sederhana terdapat tiga tahapan pengujian yaitu: (1) uji koefisien korelasi, (2) uji T statistik, dan (3) uji koefisien determinasi. 


\section{HASIL DAN PEMBAHASAN}

Tabel 2.

Karakteristik Responden

\begin{tabular}{|c|c|c|c|}
\hline \multicolumn{2}{|c|}{ Karakteristik } & \multirow{2}{*}{$\begin{array}{l}\text { Jumlah } \\
36\end{array}$} & \multirow{2}{*}{$\frac{\text { Persentase (\%) }}{60}$} \\
\hline Jenis usaha & Dagang & & \\
\hline & Industri & 15 & 25 \\
\hline & Jasa & 9 & 15 \\
\hline Total & & 60 & 100 \\
\hline \multirow[t]{6}{*}{ Bidang usaha } & Makanan / Minuman & 16 & 27 \\
\hline & Fotografi & 12 & 20 \\
\hline & Garment & 12 & 20 \\
\hline & Fashion & 8 & 13 \\
\hline & Teknologi Informasi & 8 & 13 \\
\hline & Kerajinan & 4 & 7 \\
\hline Total & & 60 & 100 \\
\hline \multirow[t]{3}{*}{ Kategori usaha } & Usaha Mikro & 26 & 43 \\
\hline & Usaha Kecil & 22 & 37 \\
\hline & Usaha Menengah & 12 & 20 \\
\hline Total & & 60 & 100 \\
\hline \multirow[t]{3}{*}{ Lama usaha } & 1-5 Tahun & 32 & 53 \\
\hline & 6-10 Tahun & 20 & 34 \\
\hline & $>10$ Tahun & 8 & 13 \\
\hline Total & & 60 & 100 \\
\hline \multirow{6}{*}{$\begin{array}{l}\text { Jenis media sosial yang paling sering } \\
\text { digunakan }\end{array}$} & Facebook & 30 & 50 \\
\hline & Twitter & 3 & 5 \\
\hline & Instagram & 17 & 28 \\
\hline & Line & 0 & 0 \\
\hline & Youtube & 0 & 0 \\
\hline & WhatsApp (WA) & 10 & 17 \\
\hline Total & & 60 & 100 \\
\hline \multirow[t]{4}{*}{ Pengeluaran untuk media sosial/bulan } & Rp $100.000-200.000$ & 15 & 25 \\
\hline & Rp $201.000-500.000$ & 34 & 57 \\
\hline & Rp $501.000-1.000 .000$ & 7 & 12 \\
\hline & $>\operatorname{Rp} 1.000 .000$ & 4 & 7 \\
\hline Total & & 60 & 100 \\
\hline \multirow[t]{3}{*}{ Frekuensi update media sosial } & Harian & 32 & 53 \\
\hline & Mingguan & 24 & 40 \\
\hline & Bulanan & 4 & 7 \\
\hline Total & & 60 & 100 \\
\hline
\end{tabular}

Sumber : Hasil Olahan

Responden dalam penelitian ini berjumlah 60 UMKM yang seluruhnya adalah UMKM yang rata-rata berada di Kota Jambi. Informasi karakteristik responden yang diperoleh berdasarkan kuesioner yang diberikan kepada 60 UMKM tersebut dianalisis lebih lanjut secara deskriptif dengan cara mengelompokkan karakteristik responden berdasarkan jenis usaha, bidang usaha, kategori usaha, lama usaha, pemanfaatan media sosial, manfaat penggunaan sosial media. Tabel 2 menerangkan bahwa jenis usaha yang banyak didapat adalah jenis usaha dagang dengan persentase $60 \%$. Hal ini membuktikan sektor perdagangan merupakan aktivitas kunci dalam bisnis UMKM di Kota Jambi. Sementara untuk bidang usaha yang mayoritas ditekuni oleh UMKM di Kota Jambi adalah bidang makanan/minuman dengan persentase 27\%. Mayoritas UMKM yang ada di Kota Jambi termasuk dalam kategori usaha mikro dengan persentase 43\%, sedangkan lama usaha yang dijalani oleh para UMKM berkisar antara 1-5 Tahun dengan persentase $53 \%$.

Untuk pemanfaatan media sosial, didapatkan bahwa facebook merupakan media sosial yang paling sering digunakan oleh sebagian besar UMKM di Kota Jambi, dengan persentase sebesar 50\%. Fenomena ini membuktikan bahwa media sosial facebook masih banyak diminati para pelaku usaha UMKM dikarenakan media sosial menyediakan banyak fitur yang memudahkan penggunanya untuk berinteraksi dengan pelanggan sekaligus membangun komunitas terutama pada halaman fanpage yang mereka miliki, selain itu media sosial ini memudahkan mereka dalam membangun relasi atau jaringan pertemanan hampir di seluruh komunitas grup yang ada di Kota Jambi, mengingat pengguna media sosial facebook yang tergolong besar di Kota Jambi. Dari aspek biaya yang dikeluarkan selama pemanfaatan media sosial sebagai media komunikasi pemasaran, didapatkan bahwa sebagian besar UMKM di 
Kota Jambi mengeluarkan biaya pada kisaran Rp 201.000 - 500.000 setiap bulannya untuk promosi di media sosial, dengan persentase sebesar $57 \%$. Sementara dari aspek frekuensi update media sosial, didapatkan bahwa sebagian besar responden atau 53\% diantaranya selalu mengupdate media sosialnya setiap hari, atau dengan kata lain sebagian besar UMKM memiliki tingkat frekuensi penggunaan media sosial yang cukup tinggi.

\section{Deskripsi Variabel Penelitian \\ Peran Media Sosial}

Hasil tanggapan responden terhadap variabel peran media sosial pada Gambar 1 menunjukkan bahwa dimensi curation mendapatkan rata-rata perolehan skor tertinggi, yaitu sebesar 3,92 dengan kriteria "baik". Hasil temuan ini menerangkan bahwa manfaat yang paling dominan dirasakan UMKM dari penggunaan media sosial adalah adanya kecenderungan konsumen untuk mereview produk yang diposting oleh UMKM dan memberikan "like" serta komentar positif pada postingan yg dibuat. Curation adalah tindakan dari memilah, menentukan dan melihat atau dalam kata lain menggambarkan isi dari akun media sosial yang dimiliki UMKM. Curation dapat membuat kandungan situs lebih bermanfaat untuk pihak lain. Curation dapat menimbulkan ketertarikan seperti ketika seseorang merasa tertarik untuk membeli suatu pakaian setelah membaca atau melihat review orang lain yang dianggap lebih menguasai bidang fashion (Evans and Mckee, 2010). Hal inilah yang dapat curation timbulkan, persepsi pembeli akan menjadi positif sehingga menimbulkan ketertarikan ketika melihat dan menilai review yang ditulis oleh orang yang dianggap lebih menguasai suatu bidang tersebut.

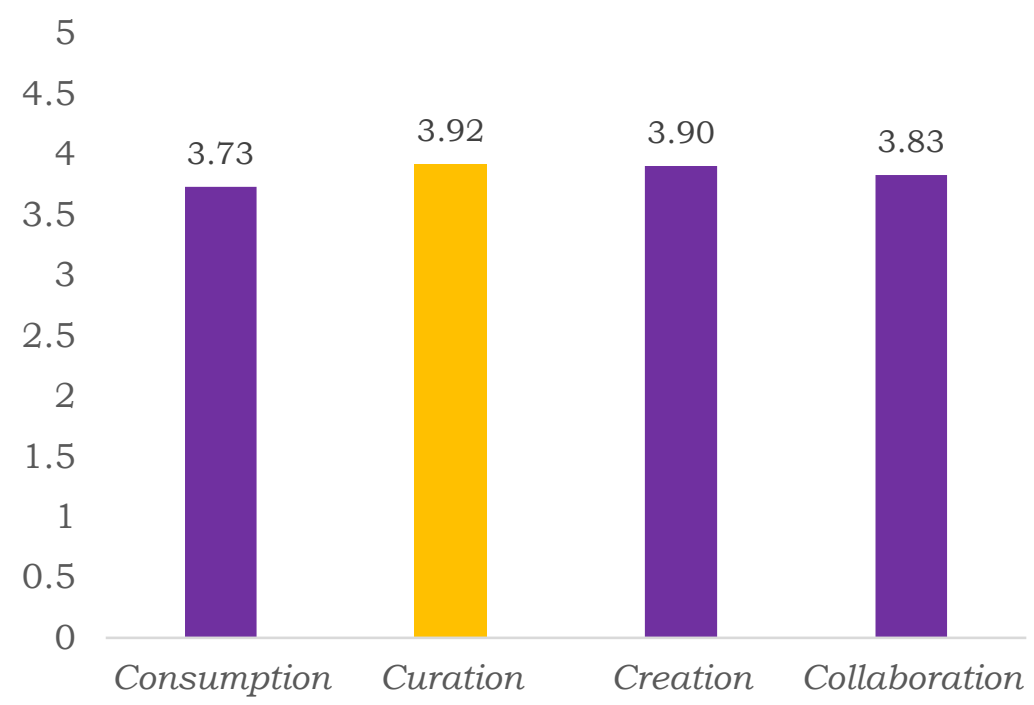

Gambar 1.

Hasil Tanggapan Responden untuk Variabel Peran Sosial Media

Hasil tanggapan responden terhadap dimensi creation pada Gambar 1 mendapatkan rata-rata perolehan skor sebesar 3,90, dengan kriteria "baik". Hasil temuan ini menerangkan bahwa manfaat yang dirasakan UMKM dari penggunaan media sosial adalah tingginya interaksi yang diukur dari besarnya tanggapan dan keterlibatan konsumen dengan produk-produk yang ditawarkan UMKM melalui media sosial. Hal ini dibuktikan dari tanggapan responden, dimana sebagain besar responden menyatakan bahwa ; (1) pelanggan merekomendasikan ke pelanggan lain melalui media sosial mengenai produk yang ditawarkan UMKM, (2) pelanggan menginformasikan keunggulan dari produk UMKM di media sosial, dan (3) pelanggan sering memberikan informasi mengenai produk UMKM ke pelanggan lainnya. Creation berkaitan dengan langkah yang menentukan sedikit banyaknya tanggapan pada suatu kejadian (Evans and Mckee, 2010). Dalam tahap ini pelaku usaha membiarkan konsumen memilih mana yang disukai dan yang tidak disukai dengan menawarkan alat, bantuan, contoh, dan fasilitas lainnya. Semakin sedikit yang usaha yang konsumen lakukan untuk memilih dan menciptakan sesuatu akan semakin baik. Menjalankan tahapan ini didasarkan pada pemikiran bahwa manusia gemar untuk membagi informasi tentang apa yang mereka lakukan dan bicarakan, dan umumnya di usahakan untuk kepentingan mereka didalam komunitas yang besar.

Hasil tanggapan responden terhadap dimensi consumption pada Gambar 1 mendapatkan rata-rata perolehan skor sebesar 3,73, dengan kriteria "baik". Hasil temuan ini menerangkan bahwa manfaat yang dirasakan UMKM dari penggunaan media sosial adalah semua konsumen mampu melihat setiap informasi atau penawaran yang disampaikan melalui akun media sosial mereka, sehingga konsumen mengetahui dengan baik produk-produk yang telah diberikan baik fungsi maupun manfaatnya. Consumption adalah tahapan pertama untuk selanjutnya memulai aktifitas online lainnya. Hal-hal yang menjadi bahan consumption adalah sesuatu yang biasanya dapat disebarkan, bukan sesuatu yang 
tidak dapat disebarkan seperti jika perusahaan menyebarkan satu berita tanpa membacanya terlebih dahulu apakah isi dari berita tersebut memberikan pengaruh pada konsumen atau tidak, maka bisa jadi berita yang di sebarkan oleh perusahaan tersebut akan sia-sia karena tidak seorang pun yang mengkonsumsi berita tersebut (Evans and Mckee, 2010). Hasil tanggapan responden terhadap dimensi collaboration (Gambar 1) mendapatkan rata-rata perolehan skor sebesar 3,83 dengan kriteria "baik". Hasil temuan ini menerangkan bahwa manfaat yang dirasakan UMKM dari penggunaan media sosial adalah adanya hubungan timbal balik yang positif antara UMKM dengan konsumen, serta adanya jaringan hubungan kerjasama antar sesama UMKM pengguna media sosial. Hal ini dibuktikan dari respon yang diberikan oleh sebagian besar responden bahwa: (1) pelanggan berpartisipasi memberikan masukan mengenai produk yang ditawarkan UMKM di media sosial, (2) pelaku UMKM bertukar pikiran dengan konsumen untuk memajukan produk yang dipasarkan di media sosial, dan (3) adanya kerjasama atau kolaborasi antar UMKM untuk meningkatkan penjualan produk di media sosial.

\section{Kinerja UMKM}

Hasil tanggapan responden terhadap variabel kinerja UMKM pada Gambar 2 menunjukkan bahwa dimensi pertumbuhan jumlah penjualan mendapatkan rata-rata perolehan skor tertinggi, yaitu sebesar 3,81 dengan kriteria "tinggi". Hasil temuan ini menerangkan bahwa penggunaan media sosial memberikan kontribusi pengaruh yang paling besar terhadap pertumbuhan penjualan UMKM.

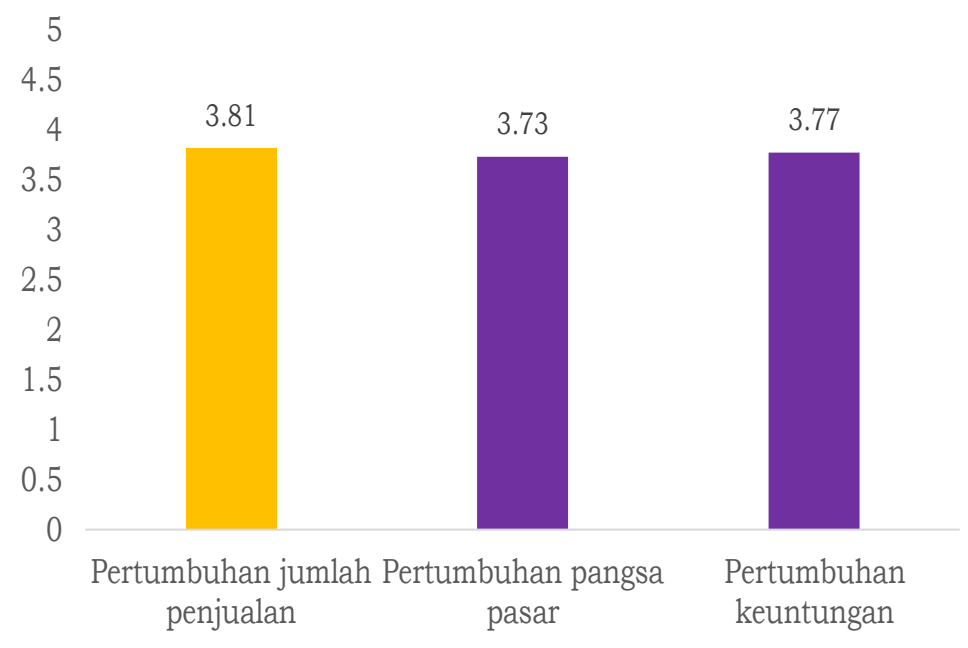

Gambar 2.

Hasil Tanggapan Responden untuk Variabel Kinerja UMKM

Berdasarkan data yang diperoleh, penggunaan media sosial dapat meningkatkan volume penjualan UKM hingga lebih dari $100 \%$, namun sebagian besar peningkatan volume penjualan masih kurang dari $50 \%$. Berdasarkan hasil observasi terhadap UKM dan media sosial yang digunakan, UKM yang berhasil meningkatkan volume penjualan hingga lebih dari $100 \%$ karena menggunakan media sosial sebagai ujung tombak komunikasi dan pemasaran perusahaan, selalu melakukan update informasi perusahaan di media sosial setiap hari. Sedangkan UKM dengan peningkatan kurang dari 50\%, sebagian besar karena lebih jarang melakukan update informasi dengan frekuensi mingguan atau bahkan bulanan. Hasil penelitian ini sesuai dengan penelitian Uitz (2012) yang menyimpulkan bahwa media sosial merupakan media komunikasi pemasaran yang sangat efektif, dapat meningkatkan ketertarikan konsumen akan merek yang ditawarkan, sehingga akhirnya dapat meningkatkan penjualan.

Hasil tanggapan responden terhadap dimensi pertumbuhan pangsa pasar pada Gambar 2 mendapatkan rata-rata perolehan skor sebesar 3,73 dengan kriteria "tinggi". Hasil temuan ini menerangkan bahwa media sosial yang digunakan UMKM juga berperan bagi peningkatan jumlah pangsa pasar UMKM. Hal ini dibuktikan dari tanggapan sebagian besar responden, yang menyatakan bahwa: (1) penggunaan media sosial memudahkan UMKM untuk mengenali pangsa pasar (market share) terhadap produk-produk yang akan ditawarkan, (2) penggunaan media sosial memudahkan UMKM untuk mengetahui penguasaan pangsa pasar (market share) dari kompetitornya, dan (3) penggunaan media sosial memudahkan UMKM untuk mencapai pangsa pasar (market share) yang telah ditargetkan.

Hasil tanggapan responden terhadap dimensi pertumbuhan keuntungan (Gambar 2) mendapatkan rata-rata perolehan skor sebesar 3,77 dengan kriteria "tinggi". Hasil temuan ini menerangkan bahwa media sosial yang digunakan UMKM juga berperan bagi peningkatan keuntungan yang diperoleh UMKM. Hal ini dibuktikan dari tanggapan sebagian besar responden, yang menyatakan bahwa: (1) penggunaan media sosial dapat menekan biaya promosi sehingga dapat meningkatkan keuntungan yang akan diperoleh, (2) penggunaan media sosial dapat 
menjangkau market lebih banyak sesuai dengan minat terhadap produk, sehingga dapat meningkatkan keuntungan yang akan diperoleh, dan (3) penggunaan media sosial dapat meningkat keuntungan hingga 30-50\%, dibandingkan keuntunggan saat belum menggunakan media sosial.

\section{Pengujian Hipotesis}

\section{Uji Normalitas Data}

Hasil pengujian (Tabel 3) menunjukkan bahwa nilai probabilitas ( $p$-value) yang diperoleh yaitu 0,207, dimana nilai ini lebih besar dari 0,05 . Dengan demikian dapat dinyatakan bahwa data yang diambil dalam penelitian ini berasal dari sampel yang berdistribusi normal.

Tabel 3

Hasil Uji Normalitas Data

\begin{tabular}{lr} 
& Unstandardized Residual \\
\hline Kolmogorov-Smirnov $Z$ & 1,064 \\
Asymp. Sig. (2-tailed) & 0,207 \\
\hline
\end{tabular}

Sumber: Data olahan

\section{Uji Linearitas}

Tabel 4 menunjukkan bahwa nilai probabilitas ( $p$-value) yang diperoleh yaitu 0,000 , dimana nilai ini lebih kecil dari 0,05. Dengan demikian dapat dinyatakan bahwa model persamaan regresi $Y=a+b X+e$ memiliki sifat linear, dalam hal ini variabel peran media sosial memiliki hubungan yang linear dengan variabel kinerja UMKM, sehingga model ini dapat digunakan untuk menggambarkan pengaruh dari peran media sosial terhadap kinerja UMKM. Merujuk pada hasil uji normalitas data dan uji linearitas, maka data yang diambil dalam penelitian ini telah memenuhi uji prasyarat hipotesis.

Tabel 4

Hasil Uji Linearitas

\begin{tabular}{|c|c|c|c|c|}
\hline Model & df & Mean Square & $\mathbf{F}$ & Sig. \\
\hline Regression & 1 & 1301,424 & 96,713 & 0,000 \\
\hline Residual & 39 & 13,457 & & \\
\hline
\end{tabular}

Sumber: Data olahan

\section{Analisis Regresi Sederhana}

Berdasarkan hasil perhitungan koefisien regresi (Tabel 5) untuk model persamaan regresi sederhana dalam penelitian ini, didapatkan model persamaan yaitu: $Y=2,600+1,037 X+0,105$. Dari model persamaan ini didapatkan dua interpretasi hubungan antara variabel kepuasan kerja dan kinerja karyawan, yaitu: (1) konstanta (a) $=2,600$, artinya jika variabel peran media sosial tidak ada atau dikendalikan, maka kinerja UMKM (Y) akan meningkat atau bertambah nilainya sebesar 2,600 persen; (2) Koefisien regresi $\mathrm{X}(\mathrm{bX})=1,037$, artinya jika terjadi peningkatan peran media sosial sebesar 1\%, maka akan meningkatkan nilai kinerja UMKM sebesar 1,037 persen.

Tabel 5

Hasil Perhitungan Koefisien Regresi dalam Analisis Regresi Sederhana

\begin{tabular}{|c|c|c|c|}
\hline \multirow{2}{*}{ Model } & \multicolumn{2}{|c|}{ Unstandardized Coefficients } & \multirow{2}{*}{$\begin{array}{c}\text { Standardized Coefficients } \\
\text { Beta }\end{array}$} \\
\hline & $\mathbf{B}$ & Std. Error & \\
\hline (Constant) & 2,600 & 5,287 & \\
\hline X & 1,037 & 0,105 & 0,847 \\
\hline
\end{tabular}

Sumber: Data olahan

\section{Uji Koefisien Korelasi}

Hasil perhitungan koefisien korelasi melalui program SPSS 21 (Tabel 6), didapatkan nilai koefisien korelasi (R) sebesar 0,847. Nilai ini berada pada rentang nilai 0,60-0,799 dengan kategori sangat kuat. Dengan demikian dapat dinyatakan bahwa variabel peran media sosial memiliki tingkat kekuatan hubungan yang kuat dengan variabel kinerja UMKM.

\section{Uji Koefisien Determinasi}

Hasil perhitungan koefisien determinasi $\left(\mathrm{R}^{2}\right)$ melalui program SPSS 21 (Tabel 6), didapatkan nilai sebesar 0,710 atau $71 \%$. Dengan demikian dapat dinyatakan bahwa variabel peran media sosial mampu menerangkan variabel kinerja UMKM dengan kontribusi pengaruh sebesar $71 \%$, sementara $29 \%$ dipengaruhi oleh variabel lain yang tidak diteliti dalam penelitian ini. 
Tabel 6

Hasil Perhitungan Nilai Koefisien Korelasi dan Nilai Koefisien Determinasi

\begin{tabular}{|c|c|c|c|}
\hline$R$ & R Square & Adjusted R Square & Std. Error of the Estimate \\
\hline $0,847^{\mathrm{a}}$ & 0,718 & 0,710 & 3,66832 \\
\hline
\end{tabular}

Sumber: Data olahan

\section{Uji $t$}

Tabel 7 menunjukkan bahwa nilai probabilitas (p-value) sebesar 0,000, dimana nilai ini lebih kecil dari 0,05, yang berarti didapat keputusan untuk menerima hipotesis bahwa variabel peran media sosial berpengaruh signifikan terhadap variabel kinerja UMKM.

Tabel 5

Hasil Uji Hipotesis dengan T Test

\begin{tabular}{cccc}
\hline & Nilai t & Df & $P$-Value \\
\hline Peran media sosial & 9,834 & 39 & 0,000
\end{tabular}

Sumber: Data olahan

Media sosial merupakan salah satu media yang mempermudah komunikasi interaktif antara pengusaha dengan siapapun, termasuk konsumen, penyalur, pemasok dan berbagai pihak yang berkepentingan, kapanpun dan dimanapun berada. Media sosial sangat membantu sebagai media penghubung informasi dan komunikasi dari produsen ke konsumen di manapun mereka berada dan berapapun jaraknya. Media sosial merupakan media yang sangat potensial untuk menemukan konsumen serta membangun image tentang merek suatu produk. Pemanfaatan media sosial pada UMKM didasari oleh kemampuan media sosial dalam membangun jaringan pertemanan untuk tertarik pada merek, logo, suara dari suatu produk UMKM. Efek inilah yang ingin dicapai ketika konsumen (teman) menyampaikan pesan merek, gambar, logo ke semua orang (teman) dalam jaringan mereka, termasuk calon konsumen yang mungkin tidak memiliki informasi lengkap tentang produk atau jasa, dan mereka yang ingin belajar dari konsumen lain yang lebih dahulu menggunakan produk UMKM. Selain itu, psikologi manusia menunjukkan bahwa orang tertarik untuk memiliki apa yang teman-teman mereka miliki, apakah mereka membutuhkannya atau tidak. Melihat produk atau mendengar tentang suatu produk yang diinformasikan oleh UKM dalam jaringan pertemanan mereka, dapat membangkitkan kebutuhan pengguna media sosial untuk berbelanja/menggunakan produk UKM tersebut.

Hasil penelitian yang didapatkan menunjukkan bahwa media sosial berpengaruh positif dan signifikan terhadap kinerja bisnis UMKM. Hal ini dibuktikan dari pengujian hipotesis menunjukkan bahwa pada tingkat signifikansi $\alpha=$ $5 \%(0,05)$, menghasilkan koefisien parameter sebesar 1,037 dan nilai $t_{\text {hitung }}$ sebesar $9,834>t_{\text {tabel }}(1,684)$ dengan tingkat signifikasi $(p$-value $)=0,000(<0,05)$. Hasil tersebut menerangkan bahwa antara media sosial yang direfleksikan oleh; (1) consumption, (2) curation, (3) creation, dan (4) collaboration berpengaruh positif dan signifikan terhadap kinerja bisnis UMKM yang direfleksikan oleh; (1) pertumbuhan penjualan, (2) pertumbuhan pangsa pasar, dan (3) pertumbuhan keuntungan. Hal ini dikarenakan media sosial memiliki kontribusi pengaruh yang cukup besar terhadap kinerja UMKM di Kota Jambi, dengan nilai kontribusi sebesar 71\%. Hasil temuan dalam penelitian ini sejalan dengan hasil temuan Priambada (2015) dan Nugroho dan Kastaman (2014), dimana pemanfaatan media sosial memiliki kontribusi yang besar terhadap kinerja bisnis UMKM. Menurut Castronovo (Permana, 2014) kegiatan perdagangan yang dimediasi oleh media sosial, dapat memberikan dampak terhadap kinerja perusahaan dari pemilik bisnis. Hal ini dikarenakan melalui penggunaan media sosial, mereka dapat meramalkan perilaku pembelian konsumen yang akan datang secara lebih akurat, meningkatkan paska popularitas merek, menarik konsumen baru, membangun kesadaran, meningkatkan penjualan, dan membangun loyalitas.

Kunci keberhasilan penerapan media sosial sepenuhnya merupakan partisipasi sebagai kebutuhan bisnis dan strategi pemasaran membutuhakan sebuah aturan main (regulasi), rutinitas otomatisasi dan dedikasi setiap hari (J. Jantsch, 2011). Satu hal yang perlu diingat adalah bahwa jaringan sosial mungkin digunakan untuk membangun hubungan jangka panjang dan jaringan pelanggan, bukan untuk langsung menciptakan pendapatan (Nugroho dan Kastaman, 2014). Hal ini menerangkan bahwa tujuan atau orientasi penggunaan media sosial bukan hanya untuk menciptakan pendapatan semata, tetapi sebagai kegiatan pendukung pemasaran untuk memenuhi target pelanggan, dengan menggunakan metode komunikasi yang tepat dan persuasif untuk mencipatkan jaringan komunitas pelanggan (customer relationship) yang seluas-luasnya. Untuk mengoptimalkan penggunaan media sosial, maka para pelaku UMKM Kota Jambi juga harus memperhatikan indeks jual media sosial yang akan digunakannya dalam aktivitas $s$ commerce. Hal ini dikarenakan setiap media sosial memiliki nilai indeks jual yang berbeda untuk kategori produk tertentu. Indeks jual ini diketahui melalui perbandingan antara jumlah responden pengguna media tertentu yang membeli kategori produk yang ditentukan dengan jumlah responden pengguna media sosial tersebut yang membeli kategori produk tersebut, serta diberi bobot berdasarkan rata-rata nilai pembeliannya. Berdasarkan hasil survey yang diperoleh Wijaya (2012) menunjukkan bahwa setiap media sosial memiliki keunggulan nilai indeks jual untuk 
kategori produk tertentu. Misalnya Facebook yang memiliki nilai indeks jual tertinggi untuk kategori fashion product, dan kaskus yang memiliki nilai indeks jual tertinggi untuk kategori food/beverages. Oleh karena itu, sudah seharusnya para pelaku UMKM Kota Jambi harus memilih dengan tepat media sosial yang akan digunakan sesuai dengan kategori produk dan nilai indeks jual media sosial tersebut.

Permana (2014) dalam penelitiannya menyatakan bahwa keberhasilan dari dampak penggunaan media sosial tersebut terhadap kinerja suatu bisnis bukan hanya merupakan akibat dari media sosial yang digunakan pelaku bisnis, melainkan ada beberapa faktor pendukung yang ikut berkontribusi dalam pengaruh antara peran media sosial terhadap kinerja bisnis, yaitu; (1) kepercayaan, (2) kompetensi sumber daya manusia, (3) konten bisnis, (4) kualitas web media sosial, (5) keinginan menggunakan (behavioral intention) serta intensitas penggunaan (use behavior) media sosial, (6) tujuan penggunaan dan (7) customer relationship management (CRM). Hal ini menerangkan bahwa peran media sosial yang direfleksikan oleh consumption, curation, creation, dan collaboration, ternyata belum memberikan kontribusi yang lebih maksimal terhadap kinerja bisnis UKM di Kota Jambi, jika tanpa didukung oleh delapan faktor pendukung tersebut dalam aktivitas bisnis mereka. Dalam lingkungan media sosial, kepercayaan adalah hubungan terarah antara dua pihak yang dapat disebut trustor dan trustee. Interaksi-interaksi di web juga harus memberikan informasi rinci mengenai transaksi, sehingga para pengguna tidak bingung, seperti informasi jaminan, kejelasan dan validitas alamat penjual. Berdasarkan keterangan yang diperoleh dari 10 UMKM di Kota Jambi, diantara calon konsumen yang berada dalam jaringan pertemanan mereka pada fanpage media sosial facebook, cukup sering ditemukan adanya keraguan pada calon konsumen mereka mengenai kebenaran informasi penawaran produk, mekanisme dan kemanan transaksi, serta jaminan/garansi pemesanan produk. Untuk membangun kepercayaan pengguna media sosial, seharusnya UMKM Kota Jambi memfasilitas respon cepat pada media sosial yang mereka gunakan, serta kemudahan pencarian dan testimonial dari pembeli lain agar memperoleh kepercayaan diri pada konsumen prospektif. Sebagian besar pengguna media sosial menggunakan transfer bank untuk pembayaran transaksi, tapi prosesnya lebih lama dari pada menggunakan online payment gateway. Bagi perkembangan mendatang, pasar dan pengguna media sosial yang memulai transaksi melalui gadget akan menuntut kecepatan transaksi tinggi. Oleh karena itu seharusnya UMKM Kota Jambi menggunakan media sosial yang memberikan kemudahan, kecepatan, dan keamanan transaksi dalam aktivitas bisnis mereka kedepannya.

Kompetensi sumber daya manusia merupakan syarat mutlak yang harus dimiliki oleh UMKM Kota Jambi dalam menjalankan aktivitas bisnis melalui media sosial. Kompetensi tersebut tidak hanya berkaitan dengan kompetensi teknologi, melainkan keterampilan teknis SDM dalam melakukan aktivitas komunikasi pemasaran di media sosial, yang meliputi; (1) keterampilan menciptakan pengaruh sosial, (2) keterampilan menciptakan kepercayaan/keyakinan konsumen, dan (3) keterampilan menjaga tingkat kebiasaan konsumen dalam berbelanja di media sosial. Ketiga keterampilan tersebut sangat dibutuhkan dalam meningkatkan trafik kunjungan konsumen (pengguna media sosial) pada media sosial yang mereka gunakan, serta tingkat kepercayaan konsumen, dan penjualan produk.

Tinggi rendahnya tingkat trafik kunjungan konsumen pada media sosial yang digunakan oleh UMKM Kota Jambi dipengaruhi oleh keinginan menggunakan (behavioral intention) serta intensitas penggunaan (use behavior) media sosial pada masyarakat Kota Jambi. Adapun faktor-faktor yang mempengaruhi behavioral intention yaitu; (1) Performance Expectancy, yaitu keyakinan konsumen bahwa dengan menggunakan internet memberikan banyak manfaat dan membantu konsumen dalam melakukan pekerjaannya, khususnya pada kegiatan belanja secara online, (2) Social Influcence, yaitu faktor-faktor sosial yang mempengaruhi konsumen menggunakan teknologi internet untuk berbelanja secara online yang berasal dari orang-orang terdekat konsumen, dan (3) Habit, yaitu kebiasaan konsumen dalam menggunakan internet untuk berbelanja online di kehidupan sehari-hari. Sementara faktor-faktor yang mempengaruhi use behavior yaitu; (1) Facilitating Condition, merupakan berbagai hal yang mampu memfasilitasi penggunaan internet seperti koneksi internet, device atau gadget yang mendukung, pengetahuan dan keterampilan serta hal lainnya yang dibutuhkan oleh konsumen dalam berbelanja secara online, (2) habit, dan (3) behavioral intention (Kamal dan Azis, 2015).

Hasil penelitian Kamal dan Azis (2015) menyebutkan bahwa konsumen memiliki keinginan menggunakan media sosial untuk berbelanja online dipengaruhi secara signifikan oleh ekspetasi kinerja, pengaruh sosial, dan kebiasaan. Sedangkan untuk intensitas menggunakan media sosial, penelitian tersebut menemukan bahwa kebiasaan dan keinginan menggunakan memiliki dampak yang signifikan. Oleh karena itu, dalam merancang sebuah strategi penjualan dengan menggunakan media sosial, UMKM Kota Jambi perlu untuk memperhatikan hal-hal sebagai berikut: (1) bagaimana meningkatkan keyakinan konsumen bahwa dengan menggunakan media sosial akan memberikan banyak manfaat dan membantu konsumen dalam melakukan pekerjaan, khususnya berbelanja online, (2) bagaimana meningkatkan pengaruh sosial kepada konsumen dari berbagai faktor yang mendorong konsumen untuk menggunakan media sosial, dan (3) bagaimana menjaga tingkat kebiasaan menggunakan media sosial dalam berbelanja online. Kualitas web dan konten bisnis pada media sosial yang digunakan oleh UMKM Kota Jambi juga ikut berkontribusi terhadap tinggi rendahnya tingkat trafik kunjungan konsumen pada media sosial. Menurut Supriyati 
(2015) kualitas yang baik dari situs jejaring sosial akan membuat pengguna merasa bahwa situs tersebut adalah kendaraan yang berguna untuk interaksi sosial, dan dapat mendorong mereka untuk terus menggunakan situs ini dan untuk bertukar informasi. Selain itu, website juga perlu menyediakan informasi produk dan aktivitas belanja, sehingga pengguna juga dapat memilih dan terus menggunakan situs tersebut. Oleh karena itu sangat beralasan bahwa kualitas website yang dirasakan pengguna akan mempengaruhi pengguna untuk loyal terhadap suatu situs belanja online.

Begitu pula dengan kualitas konten pada media sosial, dimana dalam merancang strategi pemasaran menggunakan media sosial di dalamnya, diperlukan informasi yang tepat serta sesuai dengan target konsumennya. Menurut Kamal dan Azis (2005) untuk memperoleh informasi tersebut dapat dilakukan dengan memprediksi tingkat adopsi teknologi internet untuk berbelanja online oleh target konsumennya. Konsumen memiliki tingkat adopsi yang berbeda-beda terhadap penggunaan internet untuk kegiatan berbelanja online. Hal ini disebabkan berbagai faktor yang berhubungan dengan keinginan menggunakan (behavioral intention) serta intensitas penggunaan (use behavior). Melalui pemodelan yang sistematis serta terstruktur akan dapat memberikan gambaran yang pasti mengenai informasi penawaran produk seperti apa yang akan disampaikan kepada target konsumennya. Customer relationship management (CRM) merupakan faktor yang tidak kalah pentingnya dalam meningkatkan kinerja bisnis melalui pemanfaatan media sosial. Hal ini didasari bahwa pemasukan terbesar dari proses bisnis perusahaan berasal dari pelanggan, baik secara langsung maupun tidak langsung, oleh sebab itu maka perusahaan perlu untuk mengaplikasikan CRM dalam mengidentifikasi, memuaskan dan mempertahankan pelanggan yang paling menguntungkan (Buttle dalam Chadhiq, 2007). Menurut Indah dan Devie (2013) CRM adalah strategi yang berfokus pada penciptaan kepuasan pelanggan dan hubungan jangka panjang dengan mengintegrasikan beberapa area fungsional perusahaan untuk meraih keunggulan bersaing. Chadhiq (2007) menyimpulkan dalam penelitiannya bahwa penerapan CRM yang efektif berpengaruh terhadap kinerja pemasaran dan kinerja keuangan yang terakumulasi sebagai kinerja perusahaan. Bukti ini didukung dengan penelitian Chang (2007) pada Buty Shop International Corp., MOCOTO Bank, dan Stark Technology Inc. yang menemukan adanya peningkatan kinerja pada perusahaan yang menerapkan CRM. Dalam penelitian Fazlzadeh, Ghaderi, Khodadadi, \& Nezhad (2011), Nguyen, Sherif, \& Newby (2007), Coltman, Devinney \& Midgley (2011), juga menunjukkan bahwa adanya pengaruh positif antara penerapan CRM terhadap kinerja perusahaan.

Akay (2015) dalam tulisannya tentang "Dampak Jejaring Sosial Pada Customer Relationship Management Dalam Lingkungan Bisnis" mengemukakan bahwa sebuah fenomena baru dalam memahami kebutuhan pembeli dan mencapai pelanggan baru muncul dalam bentuk teknologi SCRM (Social Customer Relationship Management), yang merupakan hasil integrasi jejaring sosial dengan customer relationship management (CRM). Merujuk pada hasil penelitian terdahulu tentang dampak CRM terhadap kinerja bisnis, maka dapat diprediksikan bahwa jika penggunaan media sosial yang dikombinasikan dengan teknologi SCRM tentunya dapat memberikan kontribusi pengaruh yang lebih besar terhadap kinerja UMKM di Kota Jambi, mengingat belum adanya dari hasil temuan di lapangan yang menunjukkan adanya implementasi teknologi SCRM oleh UMKM tersebut.

\section{SIMPULAN}

Berdasarkan hasil penelitian yang telah didapatkan, maka dapat disimpulkan sebagai berikut:

1. Hasil analisis deskriptif menunjukkan skor rata-rata jawaban responden pada setiap dimensi variabel peran sosial media berada pada rentang 3,41-4,20 dengan kriteria "baik". Adapun rinciannya sebagai berikut: Consumption sebesar 3,73; Curation sebesar 3,92; Creation sebesar 3,90; dan Collaboration sebesar 3,83.

2. Hasil analisis deskriptif menunjukkan skor rata-rata jawaban responden pada setiap dimensi variabel kinerja UMKM berada pada rentang 3,41-4,20 dengan kriteria "tinggi". Adapun rinciannya sebagai berikut: pertumbuhan jumlah penjualan sebesar 3,81; pertumbuhan pangsa pasar sebesar 3,73; dan pertumbuhan keuntungan sebesar 3,77 .

3. Hasil pengujian hipotesis membuktikan bahwa peran media sosial berpengaruh positif dan signifikan terhadap kinerja UMKM, dengan nilai kontribusi pengaruh sebesar $71 \%$.

\section{DAFTAR PUSTAKA}

Akay, Y. (2015). Dampak Jejaring Sosial pada Customer Relationship Management (CRM) dalam Lingkungan Bisnis. Artikel. Universitas Atma Jaya Yogyakarta.

Chadhiq, U. (2007). Customer Relationship Management (CRM): Pilihan Strateg iuntuk Meraih Keunggulan Bersaing.

Chang, H. H. (2007). Critical Factors and Benefits in the Implementation of Customer Relationship Management. Total Quality Management, 18 (5), 483-508

Coltman, T, Devinney, T. M. \& Midgley, D. F. (2011). Customer Relationship Management and Firm Performance. Journal of Information Technology, 26, 205-219

Evans, D., and Mckee, J. (2010). Sosial Media Marketing. Indianapolis: Wiley Publising, Inc. 
Fazlzadeh, A., Ghaderi, E., Khodadadi, H. \& Nezhad, H. D. (2011). An Exploration of the Relationship between CRM Effectiveness and the Customer Information Orientation of the Firm in Iran Markets. International Business Research, 4 (2), 238-249

Husband, S. and Purnendu, M. (1999). A Conceptual Model for Quality Inetgrated Management in Small and Medium Size Enterprise. International Journal of Quality \& Reliability Management, 16 (7), 699-713.

Indah, D.P. dan Devie. 2013. Analisa Pengaruh Customer Relationship Management Terhadap Keunggulan Bersaing Dan Kinerja Perusahaan. Business Accounting Review, 1 (2), 50-60

Jantsch, J.(2011). Let_s talk Social Media for Small Business, Microsoft live small business. Available online:www.ducttapemarketing.com/socialmediaforbusiness.pdf

Kamal, R.M. dan Elvira, A. (2015). Adopsi Teknologi Internet Oleh Konsumen UMKM Indonesia Untuk Berbelanja Online (Studi Pada Situs Tokopedia. Com Tahun 2015)

Lin, C.Y. (1998). Success Factors of Small and Medium Sized Entreprises in Taiwan : An Analysis of Cases. Journal of Small Business Management, 36 (4), 43-65.

Mahemba, C. M. (2003). Innovation Management Practices of Small and Medium Scale Enterprises In Tanzania. (Disertasi tidak diterbitkan). University of Twente, Enschede.

Nguyen, T. U. H., Sherif, J. S. \& Newby, M. (2007). Strategies for Successful CRM Implementation. Information Management \& Computer Security, 15 (2), 102-115

Nugroho, H. dan Kastaman. (2014). Pengaruh Media Sosial Facebook dalam Peningkatan Penjualan Bisnis Online. Prosiding Seminar Nasional Aplikasi Sains \& Teknologi (SNAST).

Olomi, D. R. (1999). Entrepreneurial Characteristics and Small Firm Performance. LK Rutashobya, \& D. R. Olomi,(Eds.), African entrepreneurship and small business development. Dar Es Salaam: DUP LTD.

Permana, E. (2014). Penggunaan Social Media Bagi UKM (Usaha Kecil Menengah) Pada Online Market Place.JurnalEkonomi, 23 (1)

Priambada, S. (2015). Manfaat Penggunaan Media Sosial Pada Usaha Kecil Menegah (UKM). Seminar Nasional Sistem Informasi Indonesia, 2-3 November 2015

Sugiyono. (2006). Metode Penelitian Administrasi. Bandung: Alfabeta.

Supriyati, E. (2015). Studi Empirik Social Commerce (S-Commerce) dari Sudut Pandang Kualitas Website. Fakultas Teknik, Program Studi, Teknik Informatika, and Universitas Muria Kudus, 6 (1):89-9

Tambunan, T. (2005). Promoting Small and Medium Enterprises with a Clustering Approach: A Policy Experience from Indonesia. Journal of Small Business Management, 43 (2), 138-154.

Uitz, I. (2012). Social Media - Is It Worth the Trouble?. Journal of Internet Social Networking \& Virtual Communities.

Westhead, P., \& Cowling, M. (1995). Employment change in independent owner-managed hightechnology firms in Great Britain. Small Business Economics, 7(2), 111-140.

Wijaya, E. (2012). Survey Penggunaan Media Sosial di Indonesia. Business Review, September 2012 